\title{
SPERM PENETRATION OF PIG EGGS IN RELATION TO THE TIMING OF OVULATION AND INSEMINATION
}

\author{
R. H. F. HUNTER* AND P. J. DZIUK \\ Department of Animal Science-Genetics, University of Illinois, \\ Urbana, Illinois, U.S.A.
}

(Received 3rd Fanuary 1967)

\begin{abstract}
Summary. The influence of four post-ovulatory ages of egg on the proportion of eggs penetrated by spermatozoa was studied in the pig. The time of ovulation was controlled by an injection of human chorionic gonadotrophin (HCG) given during pro-oestrus. Gilts in oestrus were inseminated $0,4,8$ or $12 \mathrm{hr}$ after the estimated time of ovulation, and eggs recovered from the oviducts in vivo either 2 or $3 \mathrm{hr}$ later. Eggs were examined from thirteen gilts in each of the four insemination groups.

A total of 515 eggs was recovered, giving an overall recovery rate of $86 \%$. Spermatozoa were found attached to or in the zona pellucida of twenty-eight of $117 \mathrm{eggs}(24 \%)$ recovered $2 \mathrm{hr}$ after insemination and in the perivitelline space of four of these eggs, but none was fertilized. Of 398 eggs recovered from forty animals $3 \mathrm{hr}$ after insemination, 208 eggs $(52 \%)$ from thirty-one animals had spermatozoa attached to or in the zona pellucida. Twenty-four of these eggs had spermatozoa in the perivitelline space, and $143(36 \%)$ were fertilized.

These findings demonstrate that boar spermatozoa can reach and penetrate the zona pellucida of pig eggs within $2 \mathrm{hr}$ of insemination, and can enter the ooplasm and cause resumption of meiosis within $3 \mathrm{hr}$ of insemination. There was no indication that post-ovulatory age as such influenced the number of spermatozoa in the zona pellucida or the proportion of eggs fertilized.
\end{abstract}

\section{INTRODUGTION}

Fertilization of pig eggs has not been observed earlier than $5 \frac{3}{4}$ to $6 \mathrm{hr}$ after mating or insemination (Thibault, 1959; Hancock, 1961; Baker \& Dziuk, 1964), although spermatozoa have been recovered from the oviducts within $1 \mathrm{hr}$ of this time (Rodolfo, 1934; Burger, 1952; Ito, Kudo \& Niwa, 1959; Pitkjanen, 1960; First, Short, Peters \& Stratman, 1965).

Hancock (1961) interpreted the 6-hr interval between mating and recovery of fertilized eggs as the time needed for spermatozoa to reach and penetrate the

\footnotetext{
* Present address: Worcester Foundation for Experimental Biology, Shrewsbury, Massachusetts, U.S.A.
} 
eggs, whereas Thibault (1959) suggested that the delay might include a period of capacitation required by boar spermatozoa. Conceivably, the timing of sperm penetration could also be influenced by the post-ovulatory age of the eggs, for Baker \& Dziuk (1964) did not observe spermatozoa in the cytoplasm of pig eggs earlier than $4 \mathrm{hr}$ after ovulation.

The present study sought to investigate more fully the timing of sperm penetration of pig eggs, and particularly to note whether the post-ovulatory age of the eggs could influence the proportion of eggs penetrated a short time after insemination. A preliminary report of our findings has already been published (Hunter \& Dziuk, 1966).

\section{Animals}

\section{MATERIALS AND METHODS}

Gilts of Yorkshire, Duroc and Yorkshire $\times$ Duroc breeding were used; all weighed between 200 and $300 \mathrm{lb}$ and were 5 to 7 months of age. They were penned and fed in groups of ten to fifteen animals, and tested for oestrus in the presence of a boar at least once daily. Gilts showing symptoms of pro-oestrus were assigned to the experiment in an arbitrary manner.

\section{Induction of ovulation}

The time of ovulation was controlled by a single intra-muscular injection of 500 i.u. HCG (Upjohn Company) in $5 \mathrm{ml}$ physiological saline given during late pro-oestrus. This stage was indicated by the swelling and colour of the vulva, and also in a proportion of the gilts by reference to the length of the previous oestrous cycle. Only gilts that would not yet stand to the boar were injected. On the basis of previous studies (Dziuk \& Baker, 1962), ovulation was assumed to occur $40 \mathrm{hr}$ after the HCG injection.

\section{Collection and insemination}

All inseminations were made with fresh, undiluted semen collected from two pure-bred Yorkshire boars; these were 12 to 18 months of age and of known fertility.

Insemination was performed intracervically using a spiral rubber catheter (Melrose \& O'Hagan, 1961) and a collapsible polythene bottle $(180 \mathrm{mI})$. The volume of semen used varied from 100 to $160 \mathrm{ml}$, usually at the upper end of this range. Insemination took place within $15 \mathrm{~min}$ of collection. Only animals that were in oestrus at the appointed time were inseminated, this being performed in their pens in the presence of the testing boar.

\section{Surgical procedures}

Gilts were removed from their pens $20 \mathrm{~min}$ before the time scheduled for egg recovery. Anaesthesia was induced by intravenous injection of a solution of sodium pentobarbital, and maintained by a halothane closed circuit system (Dziuk, Phillips \& Graber, 1964).

The reproductive tract was exposed by mid-ventral laparotomy, and the ovaries examined for the number of recent ovulations and size of unovulated Graafian follicles. The oviducts were severed from the uterine horns just 
above the utero-tubal junction, and each isthmus separated from the mesosalpinx by blunt dissection. Necessary care was taken to avoid tearing the oviduct. Approximately $20 \mathrm{ml}$ of sterile physiological saline at $37^{\circ} \mathrm{G}$ was flushed through each oviduct from the ovarian end and the flushings collected in a $50-\mathrm{ml}$ glass tube into which the free end of the oviduct had been inserted. Aseptic precautions were taken throughout these procedures.

\section{Treatment of eggs}

Eggs were located by examining the recovered fluid in a polythene Petri dish under a stereoscopic microscope $(\times 15)$, prepared individually as whole mounts and examined by phase-contrast microscopy $(\times 640)$. The eggs were then compressed more firmly, immersed for at least $24 \mathrm{hr}$ in $25 \%$ acetic alcohol, and stained with $1 \%$ natural orcein in $45 \%$ acetic acid. Particular attention was paid in the fresh specimens to the number and location of spermatozoa on or

TABLE 1

THE DISTRIBUTION OF EXPERIMENTAL ANIMALS ACGORDING TO THE AGE OF EGGS AT THE TIME OF INSEMINATION AND THE TIME OF EGG REGOVERY

\begin{tabular}{c|c|c}
\hline \multicolumn{2}{|c|}{ Age of eggs } & \multirow{2}{*}{$\begin{array}{c}\text { No. of } \\
\text { animals }\end{array}$} \\
\cline { 1 - 2 } \begin{tabular}{c|c} 
At insemination \\
$(h r)$
\end{tabular} & $\begin{array}{c}\text { At recovery } \\
(\mathrm{hr})\end{array}$ & \\
\hline 0 & 2 & 3 \\
& 3 & 10 \\
4 & 6 & 3 \\
& 7 & 10 \\
8 & 10 & 3 \\
12 & 11 & 10 \\
& 14 & 3 \\
& 15 & 10 \\
\hline
\end{tabular}

Ovulation was assumed to occur $40 \mathrm{hr}$ after an injection of 500 i.u. HCG given during pro-oestrus.

in the eggs, such observations being facilitated by rolling the egg between slide and coverglass. In the stained preparations, the configuration of the second meiotic spindle was examined in detail and the stage of penetration and morphology of any spermatozoa in the ooplasm noted.

Eggs were considered fertilized if they showed anaphase or telophase of the second meiotic division, or a second polar body together with female chromatin, and contained a spermatozoon in the ooplasm.

\section{Experimental design}

The influence of four post-ovulatory ages of egg on the proportion of eggs penetrated by spermatozoa was studied. Gilts were inseminated $0,4,8$ or $12 \mathrm{hr}$ after the estimated time of ovulation, and eggs recovered from the oviducts either 2 or $3 \mathrm{hr}( \pm 10 \mathrm{~min}$ ) later (Table 1). Eggs were examined from thirteen gilts in each of the four groups. 
Oestrous behaviour

\section{RESULTS}

Eighty-eight pro-oestrous gilts were injected with HGG. Sixty-six $(75 \%)$ of these exhibited oestrus within $40 \mathrm{hr}$ of the injection, and fifty-five $(63 \%)$ were in oestrus at the time scheduled for insemination. The interval from injection of HCG to the onset of oestrus in the inseminated animals varied from approximately $6 \mathrm{hr}$ to more than $40 \mathrm{hr}$.

\section{Ovulation rate}

In the fifty-four gilts from which eggs were recovered, a total of 623 corpora lutea was counted at laparotomy, giving a mean ovulation rate of 11.5 , with a range from 8 to 15 . Due to extremely short uterine ligaments, the ovaries and oviducts could not be exposed sufficiently in one animal to permit egg recovery.

Ovulation was complete in fifty-two of the fifty-four animals. Two gilts laparotomized at 43 and $55 \mathrm{hr}$ after HGG injection had four and six follicles,

TABLE 2

THE NUMBER OF EGGS SHED AND RECOVERED FROM PIGS AT VARIOUS INTERVALS AFTER OVULATION AND INSEMINATION

\begin{tabular}{|c|c|c|c|c|c|c|}
\hline \multirow{2}{*}{$\begin{array}{c}\text { Age of eggs at } \\
\text { insemination }(h r)\end{array}$} & \multicolumn{3}{|c|}{$\begin{array}{l}\text { Recovery at } 2 \mathrm{hr} \\
\text { after insemination }\end{array}$} & \multicolumn{3}{|c|}{$\begin{array}{l}\text { Recovery at } 3 \mathrm{hr} \\
\text { after insemination }\end{array}$} \\
\hline & $\begin{array}{c}\text { No. corpora } \\
\text { lutea }\end{array}$ & $\begin{array}{l}\text { No. } \\
\text { and }\end{array}$ & $\begin{array}{l}\text { covered } \\
\text { atage }\end{array}$ & $\begin{array}{c}\text { No. corpora } \\
\text { lutea }\end{array}$ & $\begin{array}{l}\text { No. } \\
\text { an }\end{array}$ & $\begin{array}{l}\text { covered } \\
\text { atage }\end{array}$ \\
\hline $\begin{array}{r}0 \\
4 \\
8 \\
12\end{array}$ & $\begin{array}{l}35 \\
32 \\
38 \\
35\end{array}$ & $\begin{array}{l}25 \\
25 \\
36 \\
31\end{array}$ & $\begin{array}{l}71 \cdot 4 \\
78 \cdot 1 \\
94 \cdot 7 \\
88 \cdot 6\end{array}$ & $\begin{array}{l}123 \\
113 \\
108 \\
118\end{array}$ & $\begin{array}{r}104 \\
94 \\
93 \\
107\end{array}$ & $\begin{array}{l}84 \cdot 6 \\
83 \cdot 2 \\
86 \cdot 1 \\
90 \cdot 7\end{array}$ \\
\hline Total & 140 & 117 & $83 \cdot 6$ & 462 & 398 & $86 \cdot 2$ \\
\hline
\end{tabular}

respectively, between 7 and $9 \mathrm{~mm}$ in diameter. The eggs recovered from these two gilts are not included in the observations presented below. Apart from these instances, follicles did not exceed 2 to $3 \mathrm{~mm}$ in diameter.

\section{Egg recovery}

A total of 515 eggs was recovered from fifty-two animals which, on the basis of the number of corpora lutea counted at laparotomy, represented an overall recovery rate of $86 \%$. Eighteen gilts $(35 \%)$ had the same number of ovulations as eggs recovered.

Recovery rates increased as the interval from ovulation to laparotomy increased; $71 \%$ of the eggs were recovered within $2 \mathrm{hr}$ of ovulation, $85 \%$ within $3 \mathrm{hr}$ of ovulation, and $95 \%$ within $10 \mathrm{hr}$ of ovulation (Table 2).

\section{Eggs recovered $2 \mathrm{hr}$ after insemination}

One hundred and seventeen eggs were recovered from twelve gilts $2 \mathrm{hr}$ after insemination, and spermatozoa were found attached to or in the zona pellucida 
of twenty-eight eggs $(24 \%)$ recovered from four of these gilts (Table 3 ). The number of spermatozoa seen on or in the zonae of these twenty-eight eggs ranged from one to fourteen, with a mean of five. One or more spermatozoa had penetrated the zona pellucida of eighteen eggs, but there was no indication that the post-ovulatory age of the eggs influenced the proportion that were penetrated.

Two eggs were each observed to have a spermatozoon in the perivitelline space and in one the sperm head was attached to the vitelline membrane. Two additional eggs each had two spermatozoa in the perivitelline space (Table 3 ). Spermatozoa were not observed within the ooplasm of any egg recovered $2 \mathrm{hr}$ after insemination, neither was there any sign of resumption of meiosis. The metaphase arrangement of chromosomes in all eggs was compact, no degeneration of the spindle being apparent.

TABLE 3

THE NUMBER OF EGGS EXAMINED, AND THE PROPORTION HAVING ONE OR MORE SPERMATOZOA ON OR IN THE ZONA PELLUGIDA WHEN RECOVERED 2 HR AFTER INSEMINATION

\begin{tabular}{c|c|c|c|c}
\hline $\begin{array}{c}\text { Age at } \\
\text { insemination } \\
(\text { hr })\end{array}$ & $\begin{array}{c}\text { No. } \\
\text { examined }\end{array}$ & \multicolumn{2}{|c|}{$\begin{array}{c}\text { With } \\
\text { spermatozoa }\end{array}$} & $\begin{array}{c}\text { No. } \\
\text { fertilized }\end{array}$ \\
\cline { 2 - 4 } & & No. & $\%$ & \\
\hline 0 & 25 & 5 & $20 \cdot 0$ & 0 \\
4 & 25 & $7 *$ & $28 \cdot 0$ & 0 \\
8 & 36 & $14 \dagger$ & $38 \cdot 9$ & 0 \\
12 & 31 & 2 & $6 \cdot 5$ & 0 \\
\hline Total & 117 & 28 & $23 \cdot 9$ & 0 \\
\hline
\end{tabular}

* Two eggs each had two spermatozoa in perivitelline space, and one egg had one spermatozoon in perivitelline space.

$\dagger$ One egg had one spermatozoon in perivitelline space.

The earliest that eggs were recovered fully denuded of the cumulus oophorus and corona radiata, in animals in which spermatozoa were not detected in the oviducts, was $10 \mathrm{hr}$ after ovulation. By contrast, completely denuded eggs were recovered within $6 \mathrm{hr}$ of ovulation in one gilt, on all of whose eggs spermatozoa were present. Eggs denuded except for a few corona cells were recovered within $2 \mathrm{hr}$ of ovulation in another gilt, and again spermatozoa were found on these eggs.

\section{Eggs recovered $3 \mathrm{hr}$ after insemination}

Of 398 eggs recovered from forty animals $3 \mathrm{hr}$ after insemination, 208 eggs $(52 \%)$ from thirty-one animals had spermatozoa attached to or in the zona pellucida (Tables 4 and 5). The number of spermatozoa seen on or in the zonae ranged from one to approximately eighty, with a mean of $9 \cdot 3 / \mathrm{egg}$. One or more spermatozoa had penetrated the zona of 149 of these eggs, but there was no trend in the number of spermatozoa attached to or in the zona with the post-ovulatory age of the egg. 
Spermatozoa were observed in the perivitelline space of twenty-four eggs, although in eight eggs part of the tail was still in the zona, enabling the penetration path to be followed (Pl. 1, Fig. 1). This took the form of a curve in which the spermatozoon entered the zona at a very shallow angle, but passed through the inner surface of the zona into the perivitelline space almost perpendicular to a line tangential to the surface of the egg. The sperm head was in contact with the vitelline membrane in most of these eggs; whether attachment had taken place could not be ascertained (Pl. 1, Fig. 2).

TABLE 4

THE NUMBER OF PIGS YIELDING PENETRATED AND FERTILIZED EGGS WHEN RECOVERED 3 HR AFTER INSEMINATION

\begin{tabular}{c|c|c|c}
\hline & \multicolumn{3}{|c}{ No. of animals } \\
\cline { 2 - 3 } $\begin{array}{c}\text { Age of eggs at } \\
\text { insemination }(h r)\end{array}$ & $\begin{array}{c}\text { With eggs } \\
\text { having } \\
\text { spermatozoa }\end{array}$ & $\begin{array}{c}\text { With } \\
\text { fertilized } \\
\text { eggs }\end{array}$ & $\begin{array}{c}\text { With fertilized } \\
\text { eggs from one } \\
\text { oviduct only }\end{array}$ \\
\hline 0 & 7 & 7 & 2 \\
4 & 9 & 6 & 3 \\
8 & 7 & 7 & 4 \\
12 & 8 & 8 & 10 \\
\hline Total & 31 & 28 & 4 \\
\hline
\end{tabular}

TABLE 5

THE FINDINGS ON EGGS RECOVERED 3 HR AFTER INSEMINATION

\begin{tabular}{|c|c|c|c|c|c|}
\hline $\begin{array}{c}\text { Age at } \\
\text { insemination (hr) }\end{array}$ & Examined & $\begin{array}{r}J \\
\text { sperr }\end{array}$ & th & Fertilized & $\begin{array}{c}\text { Fertilized } \\
(\text { Mean } \pm S . E .)\end{array}$ \\
\hline $\begin{array}{r}0 \\
4 \\
8 \\
12\end{array}$ & $\begin{array}{r}104 \\
94 \\
93 \\
107\end{array}$ & $\begin{array}{l}62 \\
39 \\
54 \\
53\end{array}$ & $\begin{array}{c}\% \\
59 \cdot 6 \\
41 \cdot 5 \\
58 \cdot 1 \\
49 \cdot 5\end{array}$ & $\begin{array}{l}43 \\
15 \\
43 \\
42\end{array}$ & $\begin{array}{c}\% \\
41 \cdot 4 \pm 12.9 \\
16.0 * \pm 5.4 \\
46.2 \pm 12.8 \\
39.2 \pm 10.6\end{array}$ \\
\hline Total & 398 & 208 & $52 \cdot 3$ & 143 & 35.9 \\
\hline
\end{tabular}

* Significantly different from other three groups $\left(P<0 \cdot 001 ; \chi^{2}=22 \cdot 4 ; n=3\right)$.

\section{EXPLANATION OF PLATE 1}

Pig eggs at various stages of sperm penetration. All eggs were recovered from the oviducts in vivo $3 \mathrm{hr}$ after insemination. The figures are phase-contrast photomicrographs of fresh and stained preparations.

Fig. 1. Spermatozoon in the perivitelline space with head attached to the vitelline membrane. Note the curved path of the sperm tail through the zona pellucida. Fresh preparation, $\times 540$.

FIG. 2. Spermatozoon in the perivitelline space with head (arrowed) on the surface of the vitelline membrane. Fresh preparation, $\times 540$.

Figs. 3 and 4. Egg showing a sperm head located peripherally in the ooplasm. Note the presence of the mid-piece and part of the tail, and the early stage of swelling of the sperm head. Orcein stain, $\times 1340$.

Figs. 5 and 6 . Penetrated egg showing the 'twisted' or 'waisted' appearance of the sperm head. Orcein stain, $\times 1340$. 
PLITL 1
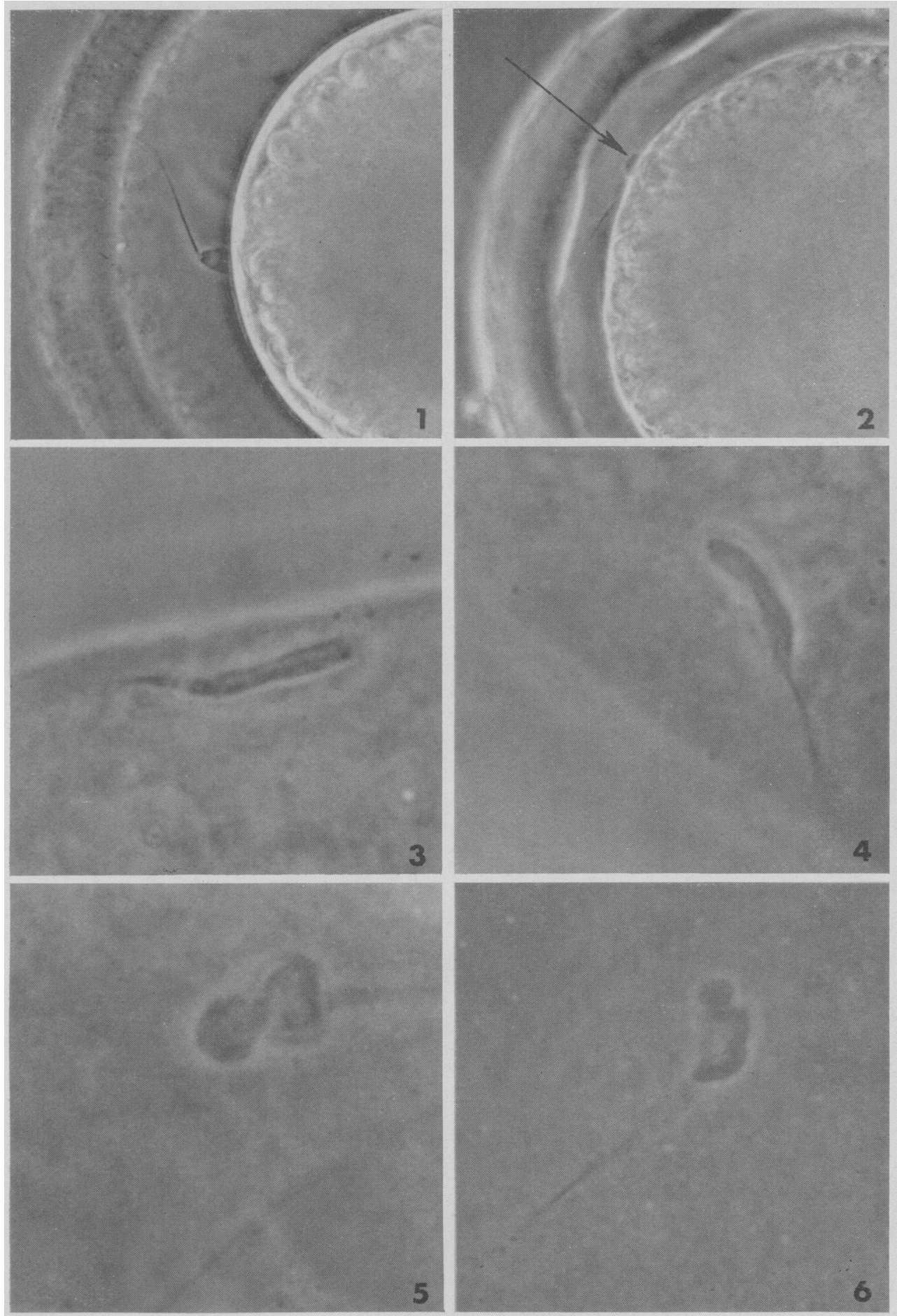

(Finitus p. 201) 
PI.SIT: -
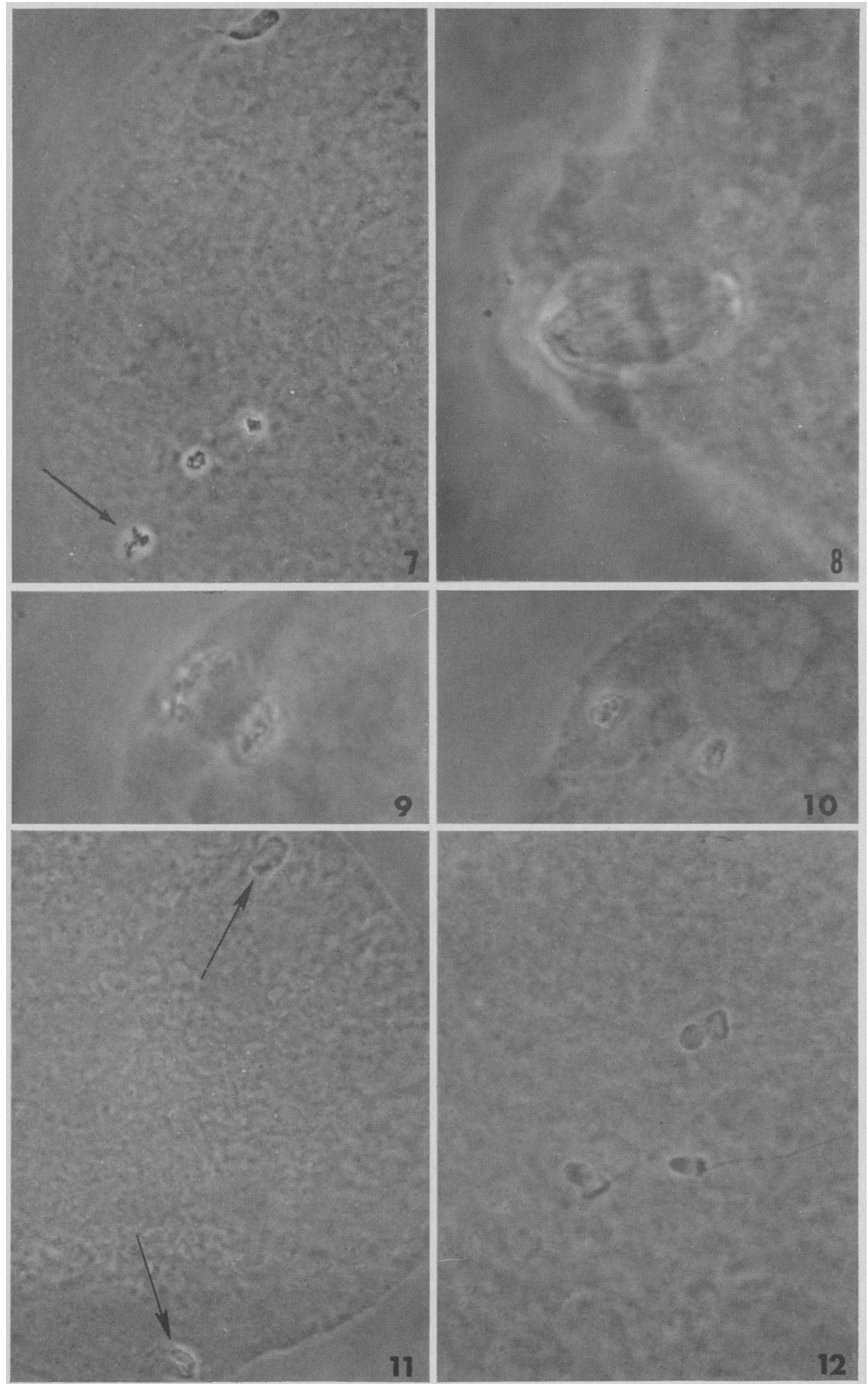
Movement of the sperm tail within the perivitelline space was seen in a number of eggs while examining fresh preparations. In one egg in which the anterior part of the sperm head appeared to be attached to the vitelline membrane, and in which part of the sperm tail was still in the zona, movement of the sperm midpiece and tail caused the vitellus to rotate, simultaneously drawing the remainder of the sperm tail into the perivitelline space. Pulsations of the ooplasm that were in rhythm with the sperm movement were also observed in this egg.

On the basis of the criteria outlined above, $143(36 \%)$ of the 398 eggs recovered $3 \mathrm{hr}$ after insemination were fertilized (Table 5). Again, there was no trend in the proportion of eggs fertilized with post-ovulatory age. The proportion of eggs fertilized following inseminations 0,8 or $12 \mathrm{hr}$ after the time of ovulation was remarkably similar, being 41,46 and $39 \%$ respectively (Table 5 ). By contrast, a significantly lower proportion of eggs was fertilized $(16 \% P<0.001)$ when insemination was performed $4 \mathrm{hr}$ after ovulation. A possible explanation of this finding is presented in the discussion.

The sperm head was located in the peripheral ooplasm of fertilized eggs and had, in nearly all instances, undergone a degree of swelling (Pl. 1, Figs. 3 and 4). In a number of eggs, this swelling gave the sperm head a characteristic 'twisted' or 'waisted' appearance (Pl. 1, Figs. 5 and 6). Despite its enlargement, the sperm head was morphologically recognizable as such except in one egg in which a male pronucleus was just being formed. The sperm midpiece and tail were still clearly associated with this structure.

The second polar body was judged to be fully formed in forty-one of the 143 $(29 \%)$ fertilized eggs. The fibres of the meiotic spindle were attached to or associated with the second polar body in many of the eggs. The remaining 102 eggs $(71 \%)$ showed anaphase or telophase of the second meiotic division (Pl. 2, Figs. 7 and 8). Again the spindle elements, including the mid-body, were clearly visible in most of these eggs, the typical fan-shaped arrangement of the fibres being seen (Pl. 2, Figs. 9 and 10). The female chromatin was always at the origin of the fan, the mid-body approximately half-way along the fibres and the chromatin of the second polar body at the top of the fan. Because of this arrangement, the female chromatin appeared as a lump whereas the chromatin of the newly formed second polar body was arranged as a fairly loose ring. Female pronuclei were not seen.

\section{EXPLANATION OF PLATE 2}

Stages in the process of fertilization of pig eggs recovered from the oviducts $3 \mathrm{hr}$ after insemination. All figures are phase-contrast photomicrographs of fixed and orceinstained preparations.

Fig. 7. A fertilized egg showing telophase of the second meiotic division. Note the 'activating' spermatozoon and the chromatin of the first polar body (arrowed). $\times 540$.

FIG. 8. The chromosomes of the second meiotic division arranged at telophase. Note the spindle fibres and condensation at the equator of the spindle. $\times 1340$.

FIGs. 9 and 10. Chromosomes of the second meiotic division arranged at telophase. Note the fan-shaped disposition of the spindle fibres, and the location of the mid-body. $\times 1080$.

FIG. 11. A dispermic egg with both sperm heads commencing to swell. Note peripheral location of the sperm heads (arrowed) in the ooplasm. $\times 335$.

FIG. 12. A trispermic egg showing morphological alteration of the sperm heads. $\times 540$. 
Within individual gilts, fertilized eggs were often at different stages of development. Thus, eggs at anaphase, telophase and with second polar bodies were recovered from the one animal in eleven instances.

Six polyspermic eggs were recovered from six animals, and in each egg the extra spermatozoa showed some degree of swelling. Four of these eggs were dispermic (Pl. 2, Fig. 11) and two were trispermic (Pl. 2, Fig. 12). With respect to the four insemination groups, one polyspermic egg was recovered in the 0-hr group, two in the 4-hr group, two in the 8-hr group, and one in the 12-hr group. There was thus no correlation between the age of egg at insemination and the incidence of polyspermy. Four of the six polyspermic eggs had more than thirty spermatozoa about them when recovered $3 \mathrm{hr}$ after insemination.

Six primary oocytes were recovered from four gilts. Four of the eggs were completely denuded of cumulus and corona cells and may have been atretic. The remaining two, recovered $11 \mathrm{hr}$ after ovulation, were embedded in a tight cumulus plug and could have been immature. Although two of the primary oocytes were recovered from oviducts yielding fertilized eggs, neither was penetrated by spermatozoa.

\section{DISCUSSION}

The results of the above study demonstrate that boar spermatozoa can reach and penetrate the zona pellucida of pig eggs within $2 \mathrm{hr}$ of insemination and can enter the ooplasm and cause resumption of meiosis within $3 \mathrm{hr}$ of insemination. These findings are thus at variance with those of Thibault (1959), Hancock (1961) and Baker \& Dziuk (1964) in which fertilization of pig eggs was not observed earlier than $5 \frac{3}{4}$ to $6 \mathrm{hr}$ after mating or insemination.

The conclusion of Thibault (1959), that the interval of approximately $6 \mathrm{hr}$ between mating and recovery of the first fertilized egg from spontaneously ovulating pigs represents a necessary delay, appears hard to justify. There is no evidence that Thibault examined eggs earlier than $5 \frac{1}{4} \mathrm{hr}$ from mating, and eggs from only three pigs were examined up to $5 \mathrm{hr} 25 \mathrm{~min}$ from mating. Moreover, the eggs considered fertilized at $5 \frac{3}{4} \mathrm{hr}$ from mating were apparently in the pronuclear stage, and may have been penetrated several hours earlier. In this context, it is difficult to know on the basis of what evidence Thibault concludes that the penetration of spermatozoa, the formation of pronuclei and their central migration in the pig are rapid phenomena, the duration of which probably never exceeds $1 \mathrm{hr}$. Clearly, the findings in the present study and those of Thibault (1959) could be reconciled to some degree if the pronuclear stage can be found 2 to $3 \mathrm{hr}$ after the spermatozoon enters the ooplasm. The same consideration applies to the findings of Hancock (1961) for spontaneously ovulating pigs, in which distinct pronuclei were observed in all nine eggs from one sow killed $6 \mathrm{hr}$ after mating.

On the basis of the results obtained from the four insemination groups, the post-ovulatory age of the egg did not appear to influence the timing of sperm penetration, as might be indicated by a difference in the proportion of eggs 
penetrated. Certainly, there was no progressive increase in the proportion of eggs fertilized with the post-ovulatory age of the eggs at insemination.

In contrast to the failure of Baker \& Dziuk (1964) to find spermatozoa in the cytoplasm of pig eggs earlier than $4 \mathrm{hr}$ after ovulation, the $41 \%$ of eggs fertilized in the present study within $3 \mathrm{hr}$ of ovulation was similar to the figures at 11 and $15 \mathrm{hr}$ from ovulation. The significant drop in the proportion of eggs fertilized in the 4-hr insemination group was possibly attributable to the disintegration of the cumulus plug before many spermatozoa reached it, with the resultant decreased chance of an egg-sperm meeting. This effect may have been compensated for in the 8- and 12-hr insemination groups since the eggs would have reached a region of higher sperm density.

Previous reports of polyspermy of pig eggs have come from studies in which mating or insemination has been delayed until after the time of ovulation (Pitkjanen, 1955; Hancock, 1959; Thibault, 1959; Hunter, 1967). Polyspermic eggs were found in the present experiment within 3 to $7 \mathrm{hr}$ of ovulation, and two spermatozoa were found in the perivitelline space of two eggs within $6 \mathrm{hr}$ of ovulation. Moreover, a mean of $9 \cdot 3$ spermatozoa/egg was counted $3 \mathrm{hr}$ after insemination, suggesting that relatively high numbers of spermatozoa adjacent to the egg at the moment of penetration, or at least before the block to polyspermy (zona reaction) becomes effective, may also be responsible for the occurrence of polyspermy. Braden, Austin \& David (1954) have demonstrated a development in the block to polyspermy spreading progressively from the point of entry of the first spermatozoon into rat and mouse eggs, and a similar phenomenon may be found in the zona pellucida of the pig egg. Thus, if two or morespermatozoa penetrate the zona simultaneously, and it is improbable that these will penetrate at the same point on the surface of the egg, then polyspermy may ensue before complete development of the zona reaction.

Recovery of eggs showing anaphase or telophase of the second meiotic division, together with those having second polar bodies, from the same animal, would suggest that completion of the second meiotic division is a rapid process, occurring within the space of $1 \mathrm{hr}$. Before resumption of meiosis can be initiated, it appears that the sperm head must have actually entered the ooplasm, or undergone fusion with the vitelline membrane. Spermatozoa in the zona pellucida or in the perivitelline space were not observed to have caused activation of the second meiotic division.

As each oviduct was flushed only once, the recovery in vivo of $86 \%$ of the eggs was considered very satisfactory. Although a recovery rate of $97 \%$ was obtained from the oviducts at autopsy by Hunter (1967), the advantages of being able to recover eggs from the live animal at a predetermined time were considered to outweigh the proportion of eggs lost. The surgical procedures, especially that of inserting a flushing needle into the top of the ampulla soon after ovulation, may have caused the loss of some eggs since recovery rates improved with the interval from ovulation.

\section{ACKNOWLEDGMENT}

This study was supported in part by U.S. Public Health Grant HD 01987, and in part by funds from the Hatch Act. 


\section{REFERENCES}

Baker, R. D. \& DziUx, P. J. (1964) Fertilization in artificially inseminated gilts. (Abstract). F. Anim. Sci. 23, 1224.

Braden, A. W. H., Austin, C. R. \& David, H. A. (1954) The reaction of the zona pellucida to sperm penetration. Aust. F. biol. Sci. 7, 391.

Burger, J. F. (1952) Sex physiology of pigs. Onderstepoort F. vet. Res. Suppl. No. 2.

Dziuk, P. J. \& Baker, R. D. (1962) Induction and control of ovulation in swine. F. Anim. Sci. 21, 697.

Dziuk, P. J., Phillips, T. N. \& Graber, J. W. (1964) Halothane closed-circuit anesthesia in the pig. Am. J. vet. Res. 25, 1773.

First, N. L., Short, R. E., Peters, J. B. \& Stratman, F. W. (1965) Transport of spermatozoa in estrual and luteal sows. (Abstract). J. Anim. Sci. 24, 917.

Hancock, J. L. (1959) Polyspermy of pig ova. Anim. Prod. 1, 103.

Hancock, J. L. (1961) Fertilization in the pig. F. Reprod. Fert. 2, 307.

Hunter, R. H. F. (1967) The effects of delayed insemination on fertilization and early cleavage in the pig. F. Reprod. Fert. 13, 133.

Hunter, R. H. F. \& Dziux, P. J. (1966) Fertilization of pig eggs three hours post-insemination. (Abstract). 7. Anim. Sci. 25, 1265.

Iтo, S., Kudo, A. \& Niwa, T. (1959) Studies on the normal oestrus in swine with special reference to proper time for service. Annls Zootech. Ser. D, Suppl., p. 105.

Melrose, D. R. \& O'HaGan, C. (1961) Investigations into the techniques of insemination in the pig. Proc. IVth int. Congr. Anim. Reprod., Hague, 4, 855.

Pitrjanen, I. G. (1955) Ovulation, fertilization and the early stages of embryonic development in pigs. Izv. Akad. Nauk S.S.S.R., Ser. Biol. 3, 120.

Prtrjanen, I. G. (1960) The fate of spermatozoa in the uterus of the sow. Z. obsc. Biol. 21, 28 (Anim. Breed. Abstr. 28, 299).

Rodolfo, A. (1934) The physiology of reproduction in swine. II. Some observations on mating. Philipp. 7. Sci. 55, 13.

Thibault, C. (1959) Analyse de la fécondation de l'oeuf de la truie après accouplement ou insémination artificielle. Annls Zootech. Ser. D, Suppl., p. 165. 